\title{
East Asian Growth Before and After the Crisis
}

\author{
NICHOLAS CRAFTS*
}

The paper surveys the literature on the growth performance of the East Asian economies, evaluates the sustainability of that performance, and provides a preliminary assessment of their long-term growth prospects in the aftermath of the current crisis. It highlights special features of East Asian growth, including unusually high factor accumulation and a favorable demographic transition, but argues that total factor productivity growth has generally been somewhat disappointing. It argues that there are downside risks to the East Asian "developmental state" model, and that it may become less attractive as these economies mature. [JEL $\mathrm{N} 15, \mathrm{~N} 25, \mathrm{~N} 35, \mathrm{O} 11, \mathrm{O} 47]$

he current Asian crisis calls for a reconsideration of the "East Asian miracle." Prima facie, it would seem to call into question some of the lessons that it has been suggested that the West should learn from Asian capitalism. All of a sudden, institutional arrangements in countries like Japan and Korea are being seen as a handicap rather than a major asset to the growth process. Recent evaluations of East Asian growth (e.g., Collins and Bosworth, 1996, p. 139) have tended to emphasize that the lessons for other countries are more to do with the prodigious mobilization of investment and savings than the pursuit of rapid productivity growth. Now, it would seem that capital accumulation is jeopardized by failures in the financial systems of some countries.

*Nicholas Crafts is a professor at the London School of Economics. This article was originally prepared as a background study for the October 1998 World Economic Outlook. The author wishes to thank Jahangir Aziz and Stephen Broadberry for helpful discussions and Regina Grafe for research assistance. 
Against this background, this paper offers a survey that may help to inform responses to the following questions-which are far too ambitious for a full answer at this time.

- What was special about East Asian growth in recent decades?

- What does the financial crisis reveal about East Asian growth?

- Has the "developmental state" Asian model outlived its usefulness?

Obviously, there are enormous differences between the countries of the region, to which this paper cannot do justice, and the paper certainly has more to say about Korea than Hong Kong Special Administrative Region (SAR). ${ }^{1}$ The argument that is developed is a view from the outside using insights from applied growth economics and European economic history rather than intimate knowledge of the region.

\section{Overview of Catch-Up Growth in East Asia and Western Europe}

The historical record strongly suggests that really rapid growth of real GDP per person is confined to cases where countries that initially lag behind the leaders in terms of income and productivity levels go through a phase of catching up. Outside such periods, growth of per capita income does not typically exceed about 3 percent a year. The end of rapid catch-up growth therefore entails a deceleration in economic growth. Krugman stressed well before the recent Asian crisis that this would happen quite soon to the "tiger" economies as growth in East Asia would run into diminishing returns (1994, pp. 77-8). Although this outlook is broadly plausible, I shall argue that forecasting the dimensions and timing of such growth slowdowns is rather difficult.

Two epochs in which remarkable catch-up growth was experienced were the early post-World War II decades in Western Europe and Japan through the mid1970 s and the last thirty years or so in several other countries in East Asia. The "golden age" saw Western European real output per hour worked grow at 4.7 percent a year between 1950 and 1973, much faster than before or since (Crafts and Toniolo, 1996, p. 2), while East Asia enjoyed average growth of real GDP per person at 4.6 a year from 1960 through the mid-1990s (Collins and Bosworth, 1996, p. 136). Details of the growth rates and output levels achieved by individual countries are shown in Tables 1 and 2. This section examines some common features of these episodes and points to some contrasts between the Asian and European cases.

It is important to distinguish two aspects of the reduction in labor productivity gaps that is characteristic of the catch-up process. One way in which shortfalls in output per worker will diminish is through reductions and ultimate elimination of shortfalls in human and physical capital per worker. This is the familiar process envisaged by traditional neoclassical models of growth, in which the transition to the steady state is characterized by a temporary period of rapid growth during which diminishing returns to investment gradually intensify. A second possibility is that the labor productivity gap stems from an inferior level of total factor productivity (TFP), reflecting some combination of lags in technological knowledge and/or the diffusion of technology, inefficient allocation of resources, and inability to achieve economies of scale. This is ruled out by assumption in the Solow or Augmented-Solow growth

${ }^{1}$ Before July 1,1997 , the territory was referred to as Hong Kong. 


\section{Table 1. Real GDP/Person in 1950, 1973, and 1996}

(\$1990 International)

\begin{tabular}{|c|c|c|c|c|c|}
\hline \multicolumn{2}{|l|}{1950} & \multicolumn{2}{|l|}{1973} & \multicolumn{2}{|l|}{1996} \\
\hline Switzerland & 8,939 & Switzerland & 17,953 & Norway & 22,256 \\
\hline United Kingdom & 6,847 & Sweden & 13,494 & Switzerland & 20,252 \\
\hline Sweden & 6,738 & Denmark & 13,416 & Denmark & 19,803 \\
\hline Denmark & 6,683 & West Germany & 13,152 & West Germany & 19,622 \\
\hline Netherlands & 5,850 & France & 12,940 & Netherlands & 18,504 \\
\hline Norway & 5,403 & Netherlands & 12,763 & France & 18,207 \\
\hline Belgium & 5,346 & United Kingdom & 11,992 & Austria & 17,951 \\
\hline France & 5,221 & Belgium & 11,905 & Belgium & 17,756 \\
\hline West Germany & 4,281 & Austria & 11,308 & Sweden & 17,566 \\
\hline Finland & 4,131 & Finland & 10,768 & United Kingdom & 17,326 \\
\hline Austria & 3,731 & Italy & 10,409 & Italy & 16,814 \\
\hline Italy & 3,425 & Norway & 10,229 & Finland & 15,864 \\
\hline Ireland & 3,325 & Spain & 8,739 & Ireland & 15,820 \\
\hline Spain & 2,397 & Greece & 7,779 & Spain & 13,132 \\
\hline Portugal & 2,132 & Portugal & 7,568 & Portugal & 12,015 \\
\hline Greece & 1,951 & Ireland & 7,023 & Greece & 10,950 \\
\hline Singapore & 2,038 & Japan & 11,017 & Hong Kong & 21,201 \\
\hline Hong Kong & 1,962 & Hong Kong & 6,768 & Singapore & 20,983 \\
\hline Japan & 1,873 & Singapore & 5,412 & Japan & 19,582 \\
\hline Malaysia & 1,696 & Taiwan & & Taiwan & \\
\hline Philippines & 1,293 & Province of China & 3,669 & Province of China & 14,222 \\
\hline Taiwan & & Malaysia & 3,167 & Korea & 12,874 \\
\hline Province of China & 922 & Korea & 2,840 & Malaysia & 7,764 \\
\hline Korea & 876 & Philippines & 1,956 & Thailand & 6,112 \\
\hline Indonesia & 874 & Thailand & 1,750 & Indonesia & 3,464 \\
\hline Thailand & 848 & Indonesia & 1,538 & China & 2,653 \\
\hline China & 537 & China & 839 & Philippines & 2,369 \\
\hline United States & 9,573 & United States & 16,607 & United States & 23,719 \\
\hline
\end{tabular}

Sources: Maddison (1995), updated using Asian Development Bank (1997) and Maddison (1997 and 1998).

models but has always loomed large in the growth accounting literature on why growth rates differ (van Ark and Crafts, 1996). Historical experiences of catch-up typically involve both aspects but not necessarily in the same proportions.

There has been a great deal of econometric investigation of international crosssections of growth since 1960. A general finding is that growth rates are inversely related to initial income levels providing that enough other right-hand side variables are included. Barro (1997) offers a nice introduction by someone who has been a central figure in this literature and whose successive specifications reflect the growing sophistication of this approach. This should not, however, be taken necessarily to indicate support for some variant of the neoclassical growth model or for the hypothesis that income levels will eventually either converge to the same level or vary only according to the capital intensity of production in the steady state. As further analysis of these large international data sets has proceeded, two important 


\section{Table 2. Growth Rates of Real GDP/Person}

(Percent a year)

\begin{tabular}{|c|c|c|c|c|c|}
\hline & 1950 & & & $1973-c$ & \\
\hline & ial Income & Growth & & nitial Income & Growth \\
\hline Switzerland & 8,939 & 3.1 & Switzerland & 17,953 & 0.5 \\
\hline United Kingdom & 6,847 & 2.5 & Sweden & 13,494 & 1.2 \\
\hline Sweden & 6,738 & 3.1 & Denmark & 13,416 & 1.7 \\
\hline Denmark & 6,683 & 3.1 & West Germany & 13,152 & 1.8 \\
\hline Netherlands & 5,850 & 3.4 & France & 12,940 & 1.5 \\
\hline Norway & 5,403 & 3.2 & Netherlands & 12,763 & 1.6 \\
\hline Belgium & 5,346 & 3.5 & United Kingdom & 11,992 & 1.6 \\
\hline France & 5,221 & 4.0 & Belgium & 11,905 & 1.8 \\
\hline West Germany & 4,281 & 5.0 & Austria & 11,308 & 2.0 \\
\hline Finland & 4,131 & 4.3 & Finland & 10,768 & 1.7 \\
\hline Austria & 3,731 & 4.9 & Italy & 10,409 & 2.1 \\
\hline Italy & 3,425 & 5.0 & Norway & 10,229 & 3.4 \\
\hline Ireland & 3,325 & 3.1 & Spain & 8,739 & 1.8 \\
\hline Spain & 2,397 & 5.8 & Greece & 7,779 & 1.5 \\
\hline Portugal & 2,132 & 5.7 & Portugal & 7,568 & 2.0 \\
\hline Greece & 1,951 & 6.2 & Ireland & 7,023 & 3.6 \\
\hline Singapore & 2,038 & 4.3 & Japan & 11,017 & 2.5 \\
\hline Hong Kong & 1,962 & 5.5 & Hong Kong & 6,768 & 5.1 \\
\hline Japan & 1,873 & 8.0 & Singapore & 5,412 & 6.1 \\
\hline Malaysia & 1,696 & 2.8 & Taiwan Province of China & 3,669 & 6.1 \\
\hline Philippines & 1,293 & 1.8 & Malaysia & 3,167 & 4.0 \\
\hline Taiwan Province of China & 922 & 6.2 & Korea & 2,840 & 6.8 \\
\hline Korea & 876 & 5.2 & Philippines & 1,956 & 0.8 \\
\hline Indonesia & 874 & 2.5 & Thailand & 1,750 & 5.6 \\
\hline Thailand & 848 & 3.2 & Indonesia & 1,538 & 3.6 \\
\hline China & 537 & 2.1 & China & 839 & 5.4 \\
\hline United States & 9,573 & 2.4 & United States & 16,607 & 1.6 \\
\hline
\end{tabular}

Sources: See Table 1.

points have emerged: (1) that the neoclassical assumption of a universal technology is quite probably false; and (2) that if, in general, there are obstacles to technological diffusion, then should the costs of technology transfer fall there may be periods of catch-up even where the underlying growth process is endogenous and long-run growth rates show no tendency to equalize across countries (Sala-i-Martin, 1994).

The Augmented-Solow model based on a production function $Y=A K^{\alpha} H^{\beta} L^{\gamma}$ with constant returns to scale has been seen as a good first approximation to international growth experience (Mankiw, Ramer, and Weil, 1992). There certainly does seem to be strong support for the proposition that there are diminishing returns to physical investment as this model would claim (Oulton and Young, 1996). Nevertheless, it seems unlikely that the view of one of these authors (Mankiw, 1995) that the neoclassical assumption of universal availability and application of technological knowledge is also valid can be sustained. A closer 
look at the data even for the countries of the Organization for Economic Cooperation and Development (OECD) suggests that a number of the implications of the Augmented-Solow model are invalid.

First, tests based on time-series econometric methods have rejected both the strong form of convergence that long-term forecasts of differences in output per person for OECD countries tend to zero and also the weaker version that long-run forecasts of output per person are proportional with a single long-term trend for all advanced countries (Bernard and Durlauf, 1995; Mills and Crafts, 1999). Second, Milbourne (1995) devised a test of the restrictions implied by the pure Augmented-Solow model with no technological catching up and applied to the OECD for the post-1960 period; he found that the restrictions were easily rejected by the data and that about half of catch-up among the OECD countries could be attributed to reductions in the TFP gap with the United States. Finally, Islam (1995) reexamined the Mankiw, Romer, and Weil (1992) results using panel data methods and found that country-specific effects are substantial; his results imply that TFP in the United States was 27.5 times the level of the lowest country in the world in 1985, compared with 16.2 in Italy and 10.5 in New Zealand.

Where catch-up growth has involved reductions in the TFP gap, it would be wrong to attribute this simply to technology transfer, although technology transfer certainly does play a part according to economic historians. For example, Nelson and Wright (1992) document the conditions (market integration, spread of multinational companies, enhanced human capital formation in Europe) that made accelerated technology transfer so prominent a feature of the European golden age. At the same time, however, a substantial part of the European TFP growth in that period seems to reflect improvements in the allocation of resources and economies of scale in the halcyon era of Fordist mass production (Maddison, 1991). In the case of Italy, where TFP growth was very rapid, a careful econometric study allowing for quasi-fixed factors of production, market power, and economies of scale found that only one-sixth of TFP growth was attributable to technological change (Rossi and Toniolo, 1992).

The upshot of this work is to suggest that countries vary both in the extent to which they catch up and in the speed with which they reduce productivity gaps. This reflects not only differences in rates of investment in physical and human capital but also the effectiveness of their assimilation of technological opportunities. Growth projections based on the convergence properties of a neoclassical growth model are unreliable. Indeed it is notable from Tables 1 and 2 that European growth slowed down and that catch-up of the United States virtually ceased in the 1970s-well before the gap in income per person had fully closed. Indeed, given that steady-state income levels may be country specific, it is hard to be confident about medium-term growth forecasts in fast-growing latecomer economies - as the case of Japan in the 1970s underlines; witness the projections based on growth accounting techniques in Denison and Chung (1976, p. 126).

The doyen of economic historians writing on this topic, Abramovitz (1986) argued that these differences in the experience of catch-up growth would reflect what he termed "social capability," of which the standard of education is an important component. In this view, human capital operates in the catch-up 
process not so much as a factor of production in the Augmented-Solow sense but rather as a determinant of the rate of change of TFP and ultimate level of TFP through catch-up. Econometric support for this formulation is found in the cross-sectional growth regression literature in the influential papers by Benhabib and Spiegel (1994) and Islam (1995).

Social capability, however, clearly involves much more than education. Abramovitz himself stressed the role of institutions and the incentive structures to which they give rise. At one level, this involves rent-seeking, the political process, and the ability of vested interests to thwart modernization of the economy rather like the sclerotic tendencies highlighted by Olson (1982). More fundamentally, the appropriation of profits is central to investment and efforts to reduce costs through innovation. This suggests the importance of political and institutional structures, which permit strong yet restrained and predictable government (Weingast, 1995). In particular, government needs to be able to protect property rights and enforce contracts but to refrain from expropriation, repudiation of its obligations, and capricious behavior. Recent work in the cross-sectional growth regressions literature appears to offer strong support for this claim using measures of institutional quality based on the International Country Risk Guide (ICRG) (Barro, 1997; Knack and Keefer, 1995).

It might be argued that central aspects of social capability concern the climate for investment and the supply of finance. A key requirement is that transaction costs are kept reasonably low and that entrepreneurs are not deterred from investing in fixed costs by opportunism and "hold-up" problems. At the same time, capital market institutions need to be able to allocate resources efficiently, to monitor borrowers effectively and to reduce obstacles to financing investment arising from asymmetric information (Levine, 1996).

In most respects, Western Europe generally had already established a political, legal, and financial infrastructure capable of supporting rapid economic growth in the late nineteenth and early twentieth centuries. In the postwar European context, the remaining step taken to reduce "hold-up" problems involved the achievement of unprecedented agreements between employers and organized labor that could create a commitment technology for good behavior by both sides in the form of wage moderation in exchange for high investment (Eichengreen, 1996). Countries that were less successful in this endeavor, such as the United Kingdom, ended up with structures of industrial relations that reduced their relative effectiveness in pursuing rapid catch-up growth (Bean and Crafts, 1996).

For Europe, embarking on the period of fast growth depended on good policy, in particular, avoiding or reversing the serious errors made in the interwar period, much more than institutional innovation. For Japan, the situation was somewhat different. The famous "Japanese economic system" of the postwar years-with its distinctive employment practices, keiretsu, main bank system, all of which can be interpreted as responses to the transactions costs problem-seems to have emerged as a result of the wartime experience (Noguchi, 1998).

Catching up is not automatic, therefore, and absence of social capability may be a crucial obstacle to growth and development in some countries. Gerschenkron (1962) provided a famous discussion of the opportunities and difficulties of 
"economic backwardness." He suggested that backward countries could achieve a take-off into very rapid growth if they could substitute for "missing prerequisites," in particular a lack of "entrepreneurship." This might be regarded as much the same thing as establishing social capability. Gerschenkron's arguments can be restated as proposing that institutional innovations - to establish larger vertically integrated enterprises, develop investment banking, provide strong cash-flows for incumbent producers, and facilitate a major role for the state in investment decisions-could solve coordination and hold-up problems for investors, mitigate problems of asymmetric information in the supply of finance for industrialization, mobilize savings, and develop infant industries. A clear implication of Gerschenkron's approach is that countries that develop rapidly from a position of initial backwardness will have a legacy of institutions that are "unorthodox" from a conventional Western standpoint. Japan is perhaps a case in point.

Obviously, there are several downsides to a Gerschenkronian development strategy. First and most obvious is that the role of the state degenerates into crony capitalism or plunder by myopic autocrats. Second, it may be that the institutional structure delivers a lot of investment but is less good at providing incentives for the efficient use of funds or innovation, as a view based on incomplete contracts or agency theory might suggest. The Soviet version of the story seems to reflect an extreme outcome of this kind, which resulted in severely diminishing returns in the context of abnormally low substitutability of capital for labor (Easterly and Fischer, 1995). Third, at some later stage, it is likely that the allocative efficiency advantages of freer capital markets will become much more attractive but the transition to such institutional arrangements may be fraught with difficulties of preventing moral hazard and eventual financial crisis where bankers and regulators lack the relevant human capital and resources. Financial deregulation has, after all, proved hard to manage in many advanced western economies (Mishkin, 1997). A fourth possibility is that the institutions that work so well at the outset eventually become dysfunctional but hard to change. Current discussions of Japanese economic prospects increasingly tend to make this point concerning the future roles of the main bank system, lifetime employment, and economic regulation (Ito, 1996).

These issues are important in the context of East Asia as strategies to achieve rapid catch-up growth bear strong resemblance in many cases to Gerschenkron's recipe. While Hong Kong SAR may have followed a western-style development strategy, the account by Rodrik (1995) of the approaches of Korea and Taiwan Province of China to mobilizing investment matches the above description rather closely. Moreover, the well-known "getting relative prices wrong" and "governed markets" approaches of, respectively, Amsden (1989) and Wade (1990) to explaining rapid growth in these countries can also be seen as having strong similarities. These cases of "late industrialization" involve a stronger and more proactive role for the state together with different approaches to coping with problems of opportunism and moral hazard from those typical in Western Europe during its catch-up phase in the 1950s and 1960s.

Economic backwardness has another dimension, not central to Gerschenkron's account, but of considerable import in East Asia and in comparisons between that region and Europe-namely, a demographic one. As economies develop from 
backwardness, they typically undergo a demographic transition in which birth and death rates both fall to much lower levels but during which there is an acceleration of population growth because the falls in mortality tend to lead those in fertility. This transition has an impact on the age structure of the population that tends initially to reduce and then to significantly increase the proportion of working age people in the population.

Western European countries had completed the demographic transition prior to the postwar golden age of economic growth. They did not therefore experience a demographic boost to labor inputs per person during this period. By contrast, East Asian countries entered into demographic transition much more recently and the proportion in the working age group rose rapidly in many cases between the early 1970s and the early 1990s. A recent analysis has suggested that this change in age structure may have offered a substantial but inherently temporary growth bonus in East Asia, on the order of 1.5 to 1.9 percent a year, not only through its impact on labor supplies but also through its effects on savings (Bloom and Williamson, 1997).

The golden age in Europe came to an end in the 1970s when TFP growth slowed down markedly and permanently, diminishing returns to capital accumulation became very apparent, and the postwar settlement between capital and labor unraveled. Oil price shocks made the growth slowdown much more dramatic in the short run but were essentially irrelevant to long-run growth outcomes. Absent the recent financial crisis, something similar might have been expected for the leading Asian exponents of catch-up growth, as Krugman (1994) and others have argued, with the additional twist of the ebbing away of favorable demographic trends.

Nonetheless, the dimensions and timing of such a slowdown are not easy to predict, as this review has demonstrated. TFP growth will have a central role both through its direct contribution to growth and its indirect impact on the speed with which incremental capital to output ratios rise. But attainable TFP levels and the rate at which TFP will approach its steady-state path depend on social capability, a concept that is not quantifiable and changes in which are not predictable, even though many of its ingredients are well understood. Given that Asian institutions, political economy, savings habits, and demography differ from those of Western Europe, the earlier experience of that region does not offer any precise guidance on the issue.

\section{Productivity Performance in East Asia}

The view expressed by Krugman (1994) that leading tiger economies are facing a growth slowdown is based on an expectation that diminishing returns will soon start to bite hard in economies where growth has come much more from factor accumulation rather than improvements in TFP. This assessment relied heavily on a growth accounting exercise in Young (1995), reported in Table 3, and seemed to place heavy emphasis on the estimate for Singapore (Krugman, 1994. p. 71). Given that the capital to labor ratio grew at over 3 percent a year in each of Korea, Singapore, and Taiwan Province of China over 1960-94 (Collins and Bosworth, 1996, p. 157), if TFP growth was relatively modest, then the onset of diminishing returns might indeed seem to be a potential problem in these economies. In fact, 


\section{Table 3. Alternative Estimates of East Asian TFP Growth}

(Percent a year)

$\begin{array}{lcccc} & \begin{array}{c}\text { Young } \\ (1994 \text { and } \\ 1995)\end{array} & \begin{array}{c}\text { Collins and } \\ \text { Bosworth } \\ (1996)\end{array} & \begin{array}{c}\text { Sarel } \\ (1997)\end{array} & \begin{array}{c}\text { Adjusted } \\ \text { Young }\end{array} \\ \text { Period } & 1966-90 & 1960-94 & 1978-96 & 1966-90 \\ \text { China } & & 4.6^{*} & & 2.4^{*} \\ \text { Hong Kong } & 2.3 & & & 1.2 \\ \text { Indonesia } & 1.2^{*} & 0.8 & 2.0 & \\ \text { Korea } & 1.7 & 1.5 & -0.8 & 1.0 \\ \text { Malaysia } & 1.1^{*} & 0.9 & 2.2 & 1.9 \\ \text { Philippines } & & -0.4 & & \\ \text { Singapore } & 0.2 & 1.5 & 2.0 & \\ \text { Taiwan Province of China } & 2.6 & 2.0 & 1.8 & \end{array}$

Notes: Adjusted Young uses revised factor share weights with capital assumed to have a weight of 0.35. Estimates marked with an asterisk refer to periods other than the column label, as follows: in column (1): 1970-85; in column (2), 1984-94; and in column (4), 1966-91.

Young's estimates have turned out to be quite controversial. Table 3 also presents the results of some other growth accounting studies for comparison.

Growth accounting typically relies on the following identity:

$$
\Delta Y / Y=\alpha \Delta K / K+\beta \Delta L / L+\Delta A / A
$$

where $\alpha$ and $\beta$ are the shares of wages and profits in national income, respectively. It is an identity because $\triangle A / A$ is defined as the growth in output not accounted for by increases in the factors of production, capital, and labor. This term is the residual after calculating all the other components of the equation and represents the contribution of TFP growth. Measurement issues are fundamental to the use of this technique and have been at the heart of the debate over Young's estimates.

The terms $\alpha$ and $\beta$ are intended to capture the elasticity of output with respect to growth of capital and labor, and approximating these elasticities by factor shares is strictly valid only under perfect competition and where private and social returns to capital are identical. In fact, in the OECD countries the use of profits share seems to be a reasonable approximation (Oulton and Young, 1996). In the Asian context, this may be more doubtful and this has prompted researchers subsequent to Young to choose $\alpha$ and $\beta$ on different grounds. Sarel (1997) bases his work on using international evidence to estimate technologically determined coefficients for each major sector of activity and then derives weighted averages for each economy according to their output composition. This leaves $\alpha$ in the range 0.28 to 0.35 , notably much lower than Young's estimate of 0.49 for Singapore. Collins and Bosworth (1996) discuss a wide range of evidence, on the basis of which they argue for the imposition of a uniform value of 0.35 for $\alpha$ in each country for international 
comparisons. Assuming a common value for $\alpha$ permits the benchmarking of performance and facilitates the use of growth accounting as a diagnostic in assessing comparative growth performance. Table 3 reports the implication of adjusting Young's estimates using $\alpha=0.35$ in all cases.

Another difference between researchers concerns the treatment of improvements in the quality of labor, in particular through education. Whereas Young (1995) and Collins and Bosworth (1996) adjust their raw labor force estimates on the basis of assumptions about rates of return to observed increases in schooling, Sarel (1997) prefers to make no adjustment, with the implication that any unmeasured improvement in labor force quality will show up in the residual, TFP growth. Moving to this procedure would typically add about 0.5 percent a year to Collins and Bosworth's TFP growth estimates.

A recent contribution by Hsieh (1997) provides a further check on Young's original results by calculating the dual measure of TFP growth, that is, that obtained by comparing the growth of output prices with the growth of the weighted average of capital and labor input prices. This method is also quite data demanding and the results are preliminary; they indicate that TFP growth was significantly higher in Singapore and Taiwan Province of China than estimated by Young (1995) — at 2.6 (for 1971-90) and 3.7 percent, respectively_-but the method does not suggest any great change for Hong Kong and Korea. Hsieh argues that official data almost certainly exaggerate the growth of the capital stock in Singapore, perhaps substantially so, and that this is a strong reason to suppose that the contribution of capital to growth was less and that that of TFP growth was more than found by other researchers.

These claims have been strongly disputed by Young (1998), who points to a number of problems with Hsieh's use of the data. His discussion provides another angle on TFP growth by providing estimates of trends in factor returns in Singapore that show growth in real wages at 3 percent a year and real rentals declining at between 1 and 2 percent a year (Young, 1998, pp. 19-20). Using $\alpha=$ 0.35 , this implies TFP growth in the range of 1.25-1.6 percent a year, similar to the estimate by Collins and Bosworth (1996).

Apart from Singapore, the other country for which TFP growth estimates are especially controversial is China. The problem here is the allowance to be made for underestimation of inflation (and thus overestimation of real output growth) in the official Chinese data. Recent estimates by $\mathrm{Hu}$ and Khan (1997) found TFP growth for 1979-94 at 3.9 percent a year, while Maddison (1998), who examined the price data in great detail, reported 2.2 percent for 1978-95. If Maddison's estimates are amended to give a weight of 0.35 to capital stock growth, TFP growth would fall to 1.7 percent a year.

There is a more subtle reason for supposing that all these TFP growth estimates are biased. They rely, as is conventional, on underlying assumptions about the nature of the production function-namely, that the elasticity of substitution between factors of production is unitary and that technological change is Hicks-neutral. Rodrik (1997) argues that the elasticity is likely in practice to be equal to less than 1 and that technological change may well have been labor saving. In that case, the conventional TFP estimate will be biased downward and is proportional to the growth of the capital to labor ratio, which has been rising steeply in the tiger economies. These points 


\section{Table 4. TFP Growth: Recent East Asia in an International Context}

$\begin{array}{lr}\text { France } & 3.1 \\ \text { Italy } & 3.2 \\ \text { Japan } & 3.6 \\ \text { United Kingdom } & 1.2 \\ \text { West Germany } & 3.3 \\ \text { China } & 1.7 \\ \text { Hong Kong } & 2.4 \\ \text { Indonesia } & 0.8 \\ \text { Korea } & 1.5 \\ \text { Malaysia } & 0.9 \\ \text { Philippines } & -0.4 \\ \text { Singapore } & 1.5 \\ \text { Taiwan Province of China } & 2.0 \\ \text { Thailand } & 1.8 \\ \text { South Asia } & 0.8 \\ & \\ \text { Africa } & -0.6 \\ \text { Middle East } & -0.3 \\ \text { Latin America } & 0.2\end{array}$

Sources: France, Japan, United Kingdom, and West Germany from Maddison (1996); Italy from Rossi, Sorgato, and Toniolo (1992); Hong Kong from Young (1995) as amended in Table 3; China from Maddison (1998) with amended capital share, see text. Remainder from Collins and Bosworth (1996). Estimates for Europe and Japan refer to 1950-73, for China, to 1978-95, for Hong Kong to 1966-91, and for others, to 1960-94.

are well taken but not readily quantifiable. Nevertheless, they lose much of their power in a comparative context since they probably also apply during the European golden age, when capital deepening was much more pronounced (Maddison, 1996) yet estimated TFP growth was much more rapid, as Table 4 reports.

Three main points emerge from this review. First, Young's original estimates are probably too low in some cases, especially with regard to Singapore, but the later estimates, which are broadly similar, do not yield much stronger TFP growth on average. Second, taking Collins and Bosworth's estimates as representative of recent work and convenient by virtue of their wide coverage, by comparison with the fast catch-up countries of Europe and Japan during their golden age, prima facie, the tigers do not perform strongly, as Table 4 reports. Third, China since the late 1970s may be a case of rapid TFP growth but it seems likely that TFP growth is seriously overestimated by official data.

Table 5 fills in the factor accumulation side of the sources of growth based on conventional assumptions about factor shares, again mainly using Collins and Bosworth (1996) as representative of recent research on Asia. The tendency for Asian countries to have substantial growth from capital accumulation is clearly shown and is underlined by the comparison with their European predecessors. This originally resulted from relatively low incremental capital-to-output ratios rather than much higher investment shares in GDP (Fukuda, 1999), although 


\section{Table 5. Sources of Growth: Golden Age Europe and Japan Versus Recent East Asia}

\begin{tabular}{|c|c|c|c|c|}
\hline \multicolumn{5}{|c|}{ (Percent a year) } \\
\hline & Capital & Labor & TFP & Output \\
\hline \multicolumn{5}{|l|}{$1950-73$} \\
\hline France & 1.6 & 0.3 & 3.1 & 5.0 \\
\hline Italy & 1.6 & 0.2 & 3.2 & 5.0 \\
\hline Japan & 3.1 & 2.5 & 3.6 & 9.2 \\
\hline United Kingdom & 1.6 & 0.2 & 1.2 & 3.0 \\
\hline West Germany & 2.2 & 0.5 & 3.3 & 6.0 \\
\hline \multicolumn{5}{|l|}{ 1960-94 } \\
\hline China & 3.1 & 2.7 & 1.7 & 7.5 \\
\hline Hong Kong & 2.8 & 2.1 & 2.4 & 7.3 \\
\hline Indonesia & 2.9 & 1.9 & 0.8 & 5.6 \\
\hline Korea & 4.3 & 2.5 & 1.5 & 8.3 \\
\hline Malaysia & 3.4 & 2.5 & 0.9 & 6.8 \\
\hline Philippines & 2.1 & 2.1 & -0.4 & 3.8 \\
\hline Singapore & 4.4 & 2.2 & 1.5 & 8.1 \\
\hline Taiwan Province of China & 4.1 & 2.4 & 2.0 & 8.5 \\
\hline Thailand & 3.7 & 2.0 & 1.8 & 7.5 \\
\hline
\end{tabular}

recently the latter have tended to be the main reason for sustaining the high contribution to growth made by capital accumulation.

Table 5 also documents the much stronger contribution made by labor force growth in Asian countries than in Europe, which is also quite important in augmenting the faster growth of total factor input in Asia than in Europe. This reflects both the demographic distinctiveness of Asia in the context of its demographic transition and, to a lesser extent, the tendency of hours worked a year to fall sharply during Europe's golden age (Crafts, 1997), an experience that has not yet been repeated in East Asia. Tables 6 and 7 report these differences in labor supply.

Thus far, our review of the evidence has been broadly supportive of the position taken by Krugman (1994)_with the exception of his severe indictment of Singapore-in that it points to factor accumulation rather than TFP growth as the aspect where East Asia's growth performance is strong relative to historical precedent. This raises a serious puzzle, however. Given the high levels of real GDP per person in leading Asian economies such as Singapore and Hong Kong SAR, how can they continue to beat the " 3 percent is as good as it gets" rule for growth in advanced economies, especially if their TFP growth is nothing extraordinary?

The resolution to this paradox may be found by consideration of productivity levels, taking into account East Asia's very different pattern of labor inputs per person compared with Western countries. The most detailed comparisons of 


\section{Table 6. Demographic Underpinnings of Labor Force Growth}

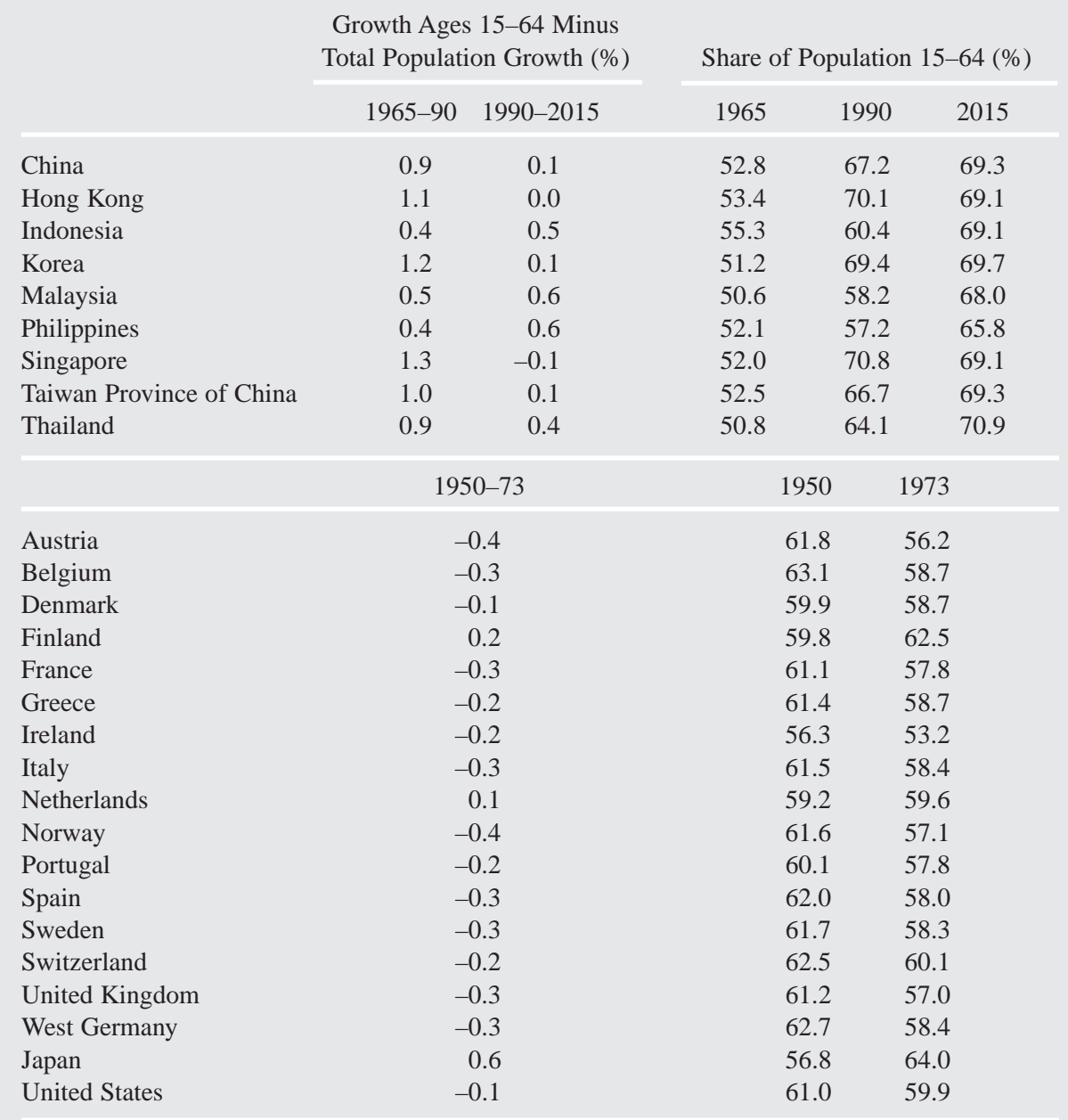

Source: Derived from United Nations (1995).

productivity levels are for manufacturing in six Asian economies by Timmer and Szirmai (1997). They found that Korea and Taiwan Province of China have been catching up with the United States such that by 1993 real output per worker in Korea and Taiwan Province of China was 49 percent and 28 percent of the U.S. level, respectively (Timmer and Szirmai, 1997, p. 15). By contrast, China's labor productivity was only 6 percent of the U.S. level-exactly the same as in 1980. For both Korea and Taiwan Province of China it is clear that catch-up with the United States has been in capital intensity rather than in TFP, which was still in the late 1980s only about 30 percent of the U.S. level so that the remaining efficiency gap is very wide. This is perhaps not so surprising given the growth accounting estimates reviewed earlier, which highlighted factor accumulation as a 


\section{Table 7. Annual Hours Worked Per Worker and Per Person}

\begin{tabular}{|c|c|c|c|c|}
\hline & \multicolumn{2}{|c|}{ Per Worker } & \multicolumn{2}{|c|}{ Per Person } \\
\hline & 1973 & 1996 & 1973 & 1996 \\
\hline Austria & 1,778 & 1,710 & 741 & 725 \\
\hline Belgium & 1,872 & 1,637 & 720 & 595 \\
\hline Denmark & 1,742 & 1,644 & 842 & 797 \\
\hline Finland & 1,915 & 1,790 & 900 & 732 \\
\hline France & 1,904 & 1,666 & 783 & 600 \\
\hline Greece & 2,000 & 1,733 & 724 & 641 \\
\hline Ireland & 2,199 & 1,694 & 763 & 622 \\
\hline Italy & 1,885 & 1,830 & 781 & 641 \\
\hline Netherlands & 1,751 & 1,487 & 692 & 592 \\
\hline Norway & 1,721 & 1,407 & 728 & 686 \\
\hline Portugal & 1,900 & 2,009 & 768 & 853 \\
\hline Spain & 2,238 & 1,810 & 818 & 559 \\
\hline Sweden & 1,571 & 1,554 & 749 & 693 \\
\hline Switzerland & 1,930 & 1,643 & 982 & 874 \\
\hline United Kingdom & 1,929 & 1,732 & 861 & 764 \\
\hline West Germany & 1,865 & 1,558 & 817 & 661 \\
\hline Hong Kong & 2,400 & 2,259 & 1,008 & 1,127 \\
\hline Indonesia & 2,010 & 2,200 & 754 & 903 \\
\hline Japan & 2,201 & 1,898 & 1,065 & 976 \\
\hline Korea & 2,428 & 2,453 & 798 & 1,099 \\
\hline Philippines & 2,235 & 2,110 & 776 & 679 \\
\hline Singapore & 2,410 & 2,318 & 872 & 1,193 \\
\hline Taiwan Province of China & 2,690 & 2,339 & 930 & 988 \\
\hline Thailand & 2,606 & 2,546 & 1,232 & 1,394 \\
\hline United States & 1,896 & 1,951 & 782 & 931 \\
\hline \multicolumn{5}{|c|}{$\begin{array}{l}\text { Sources: Estimates for } 1973 \text { are taken from Crafts (1997). Estimates for Europe, Japan, and the } \\
\text { United States in } 1996 \text { are derived from OECD (1998) and Maddison (1997) where OECD figures } \\
\text { are not available. Estimates for Hong Kong, Korea, Singapore, and Taiwan Province of China are } \\
\text { updated versions of those in Crafts (1997) and use the same sources. Estimates for other Asian } \\
\text { countries in } 1996 \text { were derived as follows: Indonesia: derived from Republic of Indonesia (1997). } \\
\text { Philippines: derived from Republic of the Philippines (1973 and 1993) assuming a 50-week work } \\
\text { year; data are for 1993, not 1996. Thailand: derived from Republic of Thailand (1973 and 1996) } \\
\text { assuming a 50-week year. }\end{array}$} \\
\hline
\end{tabular}

large part of these countries' growth. Timmer and Szirmai's comment appears apposite: "[These data] point to abundant opportunities for further catch-up growth in the Asian economies (except Japan)" (1997, p. 33).

Scope for further catch-up is certainly informed by remaining productivity gaps, even though, as Section I made clear, this potential is usually not fully realized. At the whole-economy level, comparisons of labor productivity levels are perhaps a more reliable guide than those of TFP levels given measurement difficulties. Table 8 reports these in terms of real GDP per hour worked. It is here that the further implication of the contrasting trends in labor inputs per person in East Asia and Europe becomes strikingly apparent. Once the differences in 
Table 8. Real GDP/Hour Worked, 1973 and 1996

(\$1990 International)

1973

Netherlands

Switzerland

Sweden

Belgium

France

West Germany

Denmark

Austria

Norway

United Kingdom

Italy

Finland

Greece

Spain

Portugal

Ireland

Japan

Hong Kong

Singapore

Taiwan Province of China

Korea

Philippines

Indonesia

Thailand

United States
1996

$\begin{array}{r}18.43 \\ 18.28 \\ 18.02 \\ 16.53 \\ 16.53 \\ 16.09 \\ 15.94 \\ 15.27 \\ 14.05 \\ 13.93 \\ 13.32 \\ 11.96 \\ 10.77 \\ 10.69 \\ 9.86 \\ 9.20 \\ 10.35 \\ 6.71 \\ 6.22 \\ 3.95 \\ 3.56 \\ 2.52 \\ 2.04 \\ 1.42 \\ 21.24 \\ \hline\end{array}$

18.43
18.28

18.02

16.53

16.53

16.09

5.94

15.27

13.32

11.96

10.77

10.69

9.86

10.35

6.71

6.22

3.95

3.56

2.52

1.42

21.24
Norway

Netherlands

Belgium

West Germany

France

Italy

Ireland

Sweden

Denmark

Austria

Spain

Switzerland

United Kingdom

Finland

Greece

Portugal

Japan

Hong Kong SAR

Singapore

Taiwan Province of China

Korea

Thailand

Indonesia

Philippines

United States
32.46

31.26

29.84

29.68

28.47

26.23

25.43

25.35

24.85

24.76

23.50

23.17

22.68

21.67

17.08

14.09

20.06

18.81

15.87

14.28

11.70

4.51

3.75

2.87

25.49

Source: Derived from Tables 1 and 7.

age structure and hours worked per worker each year are taken into account, the labor productivity gaps between Asia and the West are revealed to be much larger than might be supposed from simply looking at real GDP per person. The opportunity for further rapid catch-up growth has not been completely eroded even in the leading East Asian economies.

It is also important to recognize that an economy's TFP growth potential through catch-up will tend to vary over time as its social capability changes rather than simply depending on the productivity gap. In general, this will reflect institutional and policy changes and is not directly quantifiable. Nevertheless, social capability for catch-up will be influenced in part by educational standards and these are often (crudely) approximated by years of schooling of the labor force. We might expect that as countries develop they are likely to experience not only a narrowing of the productivity gap but also an improvement in educational inputs to the catch-up process. To assess the net implications for catching up in TFP it is necessary to weight schooling relative to the productivity gap. One such weighting can be obtained from the cross-sectional econometric analysis of Benhabib 


\section{Table 9. Projected Versus Actual TFP Growth}

(Percent a year)

\begin{tabular}{|c|c|c|c|c|}
\hline & $\begin{array}{c}\text { Years of } \\
\text { Schooling }\end{array}$ & Gap & $\begin{array}{l}\text { Projected } \\
\text { TFP Growth }\end{array}$ & $\begin{array}{c}\text { Actual } \\
\text { TFP Growth }\end{array}$ \\
\hline \multicolumn{5}{|l|}{ 1950-73 } \\
\hline France & 8.18 & 1.84 & 1.3 & 3.1 \\
\hline Italy & 4.92 & 2.81 & 1.4 & 3.2 \\
\hline Japan & 8.12 & 5.13 & 3.6 & 3.6 \\
\hline United Kingdom & 9.40 & 1.40 & 1.1 & 1.2 \\
\hline West Germany & 8.51 & 2.25 & 1.7 & 3.3 \\
\hline \multicolumn{5}{|l|}{ 1960-84 } \\
\hline China & 1.7 & 16.63 & 4.3 & -1.4 \\
\hline Hong Kong & 5.2 & 3.48 & 1.8 & 2.4 \\
\hline Indonesia & 1.1 & 9.90 & 2.1 & 0.8 \\
\hline Korea & 3.2 & 8.60 & 3.1 & 1.5 \\
\hline Malaysia & 2.3 & 5.74 & 1.7 & 0.9 \\
\hline Philippines & 3.8 & 7.52 & 3.0 & -0.4 \\
\hline Singapore & 3.0 & 5.62 & 2.0 & 1.5 \\
\hline Taiwan Province of China & 3.2 & 8.00 & 2.9 & 2.0 \\
\hline Thailand & 3.5 & 10.88 & 4.2 & 1.8 \\
\hline \multicolumn{5}{|c|}{$\begin{array}{l}\text { Sources: Years of schooling from Maddison (1996) and Collins and Bosworth (1996); actual } \\
\text { FP growth from Maddison (1996) and Collins and Bosworth (1996), except Italy from Rossi, } \\
\text { orgato, and Toniolo (1992) and Hong Kong from Young (1995) for 1966-91, as revised in Table } \\
\text { and China for 1952-78 adjusted from Maddison (1998). The weighting formula to produce } \\
\text { olumn (3) is derived from Benhabib and Spiegel (1994, p. 162, equation 5) and is } \\
\text {.0007 - Schooling } \text { Gap }+0.0014 \cdot \text { Gap, where Gap is defined as the ratio of the highest GDP/- } \\
\text { erson to that of the country concerned in the initial year. }\end{array}$} \\
\hline
\end{tabular}

and Spiegel (1994), which offers an interesting perspective on both on normalized success in and opportunities for catch-up TFP growth.

In effect, Table 9 extends the comparison made earlier in Table 4. It reinforces the suggestion that, in general, the European countries and Japan took more advantage of their opportunities for catch-up TFP growth, this time normalizing for schooling and productivity gaps. European countries tended to exceed the projected TFP growth, Japan matched it, and the other East Asian countries fell short, sometimes appreciably so. The result is not universal, however, and Hong Kong SAR stands out as an exception to this generalization.

Table 10 repeats the exercise of Table 9 for the East Asian countries from the perspective of later years. For the leading tigers, it is clear that increases in schooling have not outweighed the closing of the productivity gap, although recognizing the rather greater productivity gap with the United States in terms of hours worked would modify the projections a little bit, as Table 10 shows. At the same time, it is striking that actual TFP growth appears to have been much stronger recently in several cases, for example, in Korea and Thailand, and to have exceeded the projections in some countries, notably in Singapore and 


\section{Table 10. Benhabib and Spiegel TFP Growth Projections}

(Percent a year)

\begin{tabular}{|c|c|c|c|c|}
\hline & $\begin{array}{l}\text { Years of } \\
\text { Schooling }\end{array}$ & Gap & $\begin{array}{c}\text { Projected } \\
\text { TFP Growth }\end{array}$ & $\begin{array}{c}\text { Actual } \\
\text { TFP Growth }\end{array}$ \\
\hline \multicolumn{5}{|l|}{ 1984-94 } \\
\hline China & 3.6 & 14.04 & 5.5 & 1.7 \\
\hline Indonesia & 3.8 & 9.86 & 4.0 & 0.9 \\
\hline Korea & 7.9 & 3.47 & 2.4 & 2.1 \\
\hline Malaysia & 5.4 & 4.32 & 2.2 & 1.4 \\
\hline Philippines & 6.5 & 9.67 & 5.8 & -0.9 \\
\hline Singapore & 4.6 & 1.92 & 0.9 & 3.1 \\
\hline Taiwan Province of China & 6.9 & 2.79 & 1.7 & 2.8 \\
\hline \multirow[t]{2}{*}{ Thailand } & 5.1 & 7.20 & 3.6 & 3.3 \\
\hline & & & $\begin{array}{c}\text { Projected } \\
\text { TFP Growth (1) }\end{array}$ & $\begin{array}{c}\text { Actual } \\
\text { TFP Growth (2) }\end{array}$ \\
\hline \multicolumn{5}{|l|}{1996} \\
\hline China & 5.3 & 8.47 & 4.3 & \\
\hline Indonesia & 5.0 & 6.85 & 3.4 & 3.4 \\
\hline Korea & 9.7 & 1.84 & 1.5 & 1.8 \\
\hline Malaysia & 7.0 & 3.05 & 1.9 & \\
\hline Philippines & 7.4 & 10.01 & 6.6 & 5.8 \\
\hline Singapore & 6.1 & 1.13 & 0.6 & 0.9 \\
\hline Taiwan Province of China & 6.2 & 1.67 & 1.0 & 1.0 \\
\hline Thailand & 7.5 & 3.88 & 2.6 & 2.6 \\
\hline
\end{tabular}

Sources: As for Table 9, except that Projected TFP Growth (2) uses the ratio of U.S. GDP/hour worked to that of the country concerned derived using Table 8.

Taiwan Province of China. It would seem that other aspects of social capability have been changing favorably so as to enhance the efficiency with which resources are used and/or technology can be improved. Once again, this is a far more optimistic basis on which to assess future growth prospects than might be gained from a reading of Krugman (1994).

In sum, this review of productivity performance in East Asia leads to the following conclusions:

- Neither levels nor growth rates of East Asian total factor productivity have been as strong as the person in the street might suppose.

- Accordingly, productivity gaps with the West are still quite large and there remains a good deal of scope for rapid catch-up growth before diminishing returns to heavy capital accumulation bite severely.

- Exploiting this potential is not automatic but will depend on continuing to improve social capability.

- The recent TFP growth of much of the region is considerably more impressive than that of the early years of rapid economic growth.

Taken together, these points imply that growth potential is probably a good deal stronger than Krugman's pessimism would allow. 


\section{Downside Risks of the Developmental State}

Section I recalled the argument in Gerschenkron (1962) that initially backward countries have an opportunity for rapid catch-up if they take radical measures to promote development through institutional innovations and controlled capital markets. It was also remarked that this would tend to leave a legacy of institutions different from the standard U.S. model and that, especially in the longer term, there were a number of downside risks of this type of strategy. With the exception of Hong Kong SAR, the fast-growing countries of East Asia all have some similarities with the Gerschenkron model and it seems useful, especially in the context of the present crisis, to ask to what extent the downside risks have materialized.

This should not be done without first recognizing the strong positives, at least for the more successful Asian economies. These include not only the mobilization of very high rates of domestic saving and investment but also unusually strong efforts to accumulate human capital and to improve and develop imported technology. Imports of capital goods and foreign direct investment have clearly been central components of technology transfer (Dahlman, 1994). A recent World Bank report emphasized the success of Korea, Singapore, and Taiwan in rapid development of the information technology industry through effective public-private sector partnership to overcome potential market failures in the diffusion of new technology (Hanna, Boyson, and Gunaratne, 1996). The tigers' prowess in technology transfer suggests that the underperformance in TFP growth reflected especially in Table 9 has its roots in other weaknesses in the developmental state model.

Recent empirical work has stressed the importance of institutional quality for economic growth outcomes (Barro, 1997; Knack and Keefer, 1995). A clear risk of a Gerschenkronian development strategy is that it is perverted into opportunities for rent-seeking and corruption that ultimately undermine economic growth. This has clearly happened in some Asian countries and it has been suggested using the same ICRG measure of institutional quality that this discriminates very well between the winners and losers in Asian catch-up growth (Rodrik, 1997). Table 11 reports the ICRG scores of East Asian countries and also displays scores for a similar measure, BERI, which has also been used in the regression studies and has the advantage that it is first available for 1972 whereas ICRG did not appear until 1984 for most countries.

Table 11 does show some marked differences between Asian countries. When the scores are first reported, Hong Kong SAR, Singapore, and Taiwan Province of China look similar to the best European counterparts, whereas Indonesia and Philippines look much less well placed. Korea is well behind the strongest countries in the table. Poor scores are unfortunate because econometric analysis shows a strong link between corruption and foreign investment, which is just as evident in East Asia as elsewhere in the world. Corruption has a similar impact to imposing very high taxes on foreign direct investment (Wei, 1997). At the same time, Table 11 also reports some quite strong improvements by 1995, at least on the ICRG index, and a more encouraging picture overall in that year.

A second danger of the Gerschenkronian approach to development is that it spawns government policies that serve the interests of special interest groups and 


\begin{tabular}{|c|c|c|c|c|}
\hline \multicolumn{5}{|c|}{ Table 11. BERI and ICRG Index Scores } \\
\hline & BERI 1972 & BERI 1995 & ICRG 1984 & ICRG 1995 \\
\hline China & & 7.3 & & \\
\hline Hong Kong & & & 49.0 & 46.7 \\
\hline Indonesia & 6.6 & 7.0 & 15.0 & 35.7 \\
\hline Korea & 9.2 & 9.0 & 28.7 & 45.0 \\
\hline Malaysia & 9.4 & 8.8 & 41.2 & 37.0 \\
\hline Philippines & 7.8 & 6.7 & 13.0 & 32.0 \\
\hline Singapore & 12.2 & 13.2 & 47.5 & 45.0 \\
\hline Taiwan Province of China & 11.0 & 11.5 & 44.0 & 43.3 \\
\hline Thailand & & 8.4 & 30.9 & 38.7 \\
\hline \multicolumn{5}{|c|}{$\begin{array}{l}\text { Sources: Data supplied by the collecting agencies. BERI is an index aggregating "bureaucratic } \\
\text { delays," "nationalization potential," "contract enforceability" and infrastructure quality" and has a } \\
\text { maximum score of 16. ICRG is an index aggregating "quality of the bureaucracy," "corruption in } \\
\text { government," "rule of law," "expropriation risk" and "repudiation of contracts by government" with } \\
\text { a maximum score of } 50 \text {. }\end{array}$} \\
\hline
\end{tabular}

actually inhibit economic growth by inducing misallocations of resources, for example, through so-called "industrial policy." Although there is no consensus in the literature on the overall effects of these policies, even in the fast-growing economies, econometric analysis is increasingly tending to find that selective interventions on balance retarded rather than stimulated growth. An analysis of industrial productivity growth across sectors in Korea during 1963-83 found that tax and financial incentives did not enhance productivity growth, while nontariff barriers to trade reduced both capital accumulation and TFP growth (Lee, 1995). There is also evidence that Japanese industrial policies diverted resources away from high-growth sectors toward declining industries and did not have a positive effect on TFP growth within sectors during the period 1960-90 (Beason and Weinstein, 1996). Similar results apply to Taiwan Province of China in the 1980s (Smith, 1995). A drawback of the allocation of credit by government, whether directly or indirectly, is that rates of return will not be equalized across sectors. Indeed, the weakness of the Korean system of allocating credit is highlighted by its failure to stimulate either profitability or productivity growth (Borensztein and Lee, 1999).

A third class of problems arises from the desirability of reforming the initial institutional arrangements that facilitate the initial phase of rapid growth when solving coordination problems is perhaps the most dominant concern. In more mature economies, the advantages of financial liberalization will create strong pressures for reform even in relatively successful cases of "getting prices wrong," such as Korea. Yet, the eventual outcome of the financial liberalization process for Korea has been a major financial crisis in 1997/98 that was made more likely by its earlier approach to economic development.

The financial sector policies of a developmental state tended to place little weight on auditing, capital adequacy, credit rating, disclosure requirements, 
prudential regulation, or risk management (Park, 1994). Recent analysis of East Asian financial systems suggests that these failings, and an associated greater exposure to financial crisis in the face of macroeconomic shocks, were much more characteristic of countries that followed the developmental state model, with the notable exception of Singapore, than the relatively laissez-faire approach of Hong Kong SAR (Caprio, 1998).

Asymmetric information, implicit guarantees for depositors, and weak bank balance sheets_-partly reflecting continued political pressures to support favored enterprises: these are the makings of a classic recipe for moral hazard and a serious risk of financial crisis as liberalization proceeds unless regulators with incentives and powers to take prompt corrective action are available. This is the more true because the government itself is unlikely to be able to eliminate the moral hazard problem by credibly promising not to provide implicit deposit insurance. As capital markets are opened up to external flows, the overborrowing that is symptomatic of this situation tends to be reflected in excessive capital inflows and the eventual crisis will include a loss of confidence by foreign lenders and depositors (McKinnon and Pill, 1996).

What then does the current crisis tell us about the preceding East Asian growth process? It should not be taken to suggest that several decades of strong growth should be seen as some sort of mirage. Rather, it reminds us that without adequate regulation of the banking system, severe disruptions to economic growth are very possible. Economic history offers many examples of financial crises in basically sound and strong economies with high growth potential where the banking system was fragile, for example, in nineteenth and early twentieth century United States, and most notoriously in the U.S. Great Depression of the 1930s.

\section{Growth Prospects With and Without the Crisis}

One way to provide an illustrative benchmark for future growth prospects is to consider what a steady-state growth path for real GDP per person might look like and then to compare the outcome with past performance. This approach has recently been adopted for ASEAN countries by Sarel (1997) and for transition economies by the EBRD (1997). The starting point for any such calculation is to choose an estimate for TFP growth and growth of labor inputs per person. Capital accumulation is assumed to come into line as in an Augmented-Solow or endogenous innovation growth model. The results of an exercise of this type are shown in Table 12.

Before considering Table 12 in detail, it is vital to recognize that the numbers in it are not forecasts, although they may represent feasible paths that each country could sustain. The discussion of Section I gave many reasons why exercises of this kind only produce benchmarks. In particular, it argued that forecasting TFP growth during catch-up is extremely difficult because it depends on social capability and policy choices and cannot be inferred from the predictions of a pure neoclassical convergence model. Feasible TFP growth relies on scope for catch-up and the projections in Table 12 therefore make use of the analysis of Table 10; realizing this potential depends on good policy and is certainly not 


\section{Table 12. Illustrative Steady-State Growth Projections}

(Percent a year)

\begin{tabular}{|c|c|c|c|c|c|c|c|c|}
\hline & $T F P$ & $\begin{array}{l}\text { Labor/ } \\
\text { Person }\end{array}$ & $K / Y$ & I/Yreqd & $\begin{array}{l}G D P / \\
\text { pop }\end{array}$ & $\begin{array}{c}2015 \\
\text { income }\end{array}$ & $\begin{array}{c}S / Y \\
1991-96\end{array}$ & $\begin{array}{c}I / Y \\
1991-96\end{array}$ \\
\hline China & 3.6 & 0.8 & 1.7 & 21.1 & 6.3 & 8,998 & 40.1 & 39.2 \\
\hline Indonesia & 3.4 & 1.2 & 2.8 & 35.8 & 6.4 & 11,253 & 32.1 & 34.7 \\
\hline Korea & 2.2 & 0.6 & 2.9 & 28.1 & 4.0 & 27,120 & 35.4 & 36.9 \\
\hline Malaysia & 1.9 & 1.1 & 2.5 & 27.0 & 4.0 & 16,354 & 35.0 & 41.5 \\
\hline Philippines & 3.6 & 1.1 & 2.0 & 26.6 & 6.6 & 7,970 & 19.0 & 22.2 \\
\hline Singapore & 1.3 & 0.6 & 2.9 & 24.7 & 2.6 & 34,165 & 47.8 & 34.6 \\
\hline Taiwan Province of China & 1.4 & 0.6 & 1.8 & 15.5 & 2.8 & 24,031 & 27.4 & 23.4 \\
\hline Thailand & 2.6 & 1.4 & 2.2 & 23.8 & 4.9 & 15,210 & 34.9 & 42.6 \\
\hline
\end{tabular}

Sources: TFP: projected TFP growth based on catch-up component using Benhabib and Spiegel (1994, p. 162, equation 5) except for China and Philippines, where it is assumed that catchup would not exceed Japanese TFP growth in 1950-73, and Korea, Singapore, and Taiwan Province of China, where the development of a research and development capability is assumed to add a further 0.4 percent a year to TFP growth. Labor/person: projected growth of labor inputs per person derived from United Nations (1995) and an addition of 0.5 percent a year $(0.7$ percent in China, Indonesia, and Singapore) for improved labor force quality from extra schooling based on past trends as estimated by Collins and Bosworth (1996). K/Y: the 1994 capital to output ratio (Collins and Bosworth, 1996, p. 189). I/Yreqd: the percentage of GDP needed to be invested to maintain the capital to labor ratio along the steady-state path, assuming 5 percent of the capital stock depreciates each year and $\alpha=0.35$. The steady-state growth path is characterized by a constant capital to output ratio in which case

$$
\Delta Y / Y=\Delta L / L+\frac{\Delta A / A}{(1-\alpha)} .
$$

GDP/Pop: derived steady-state growth rate for real GDP per head. 2015 income: projected real GDP per person measured in 1990 \$ international (comparable with the estimates in Table 1) assuming the steady state is maintained. $S / Y$ : the domestic savings ratio (Asian Development Bank, 1997). I/Y: the domestic investment ratio (Asian Development Bank, 1997).

automatic. For example, the TFP projections for China, Indonesia, and the Philippines far exceed their recent performance and would surely require major supply-side reforms to be realized, including improvement of their BERI and ICRG scores (see Table 11) to the Singaporean level. This would not only curtail rent-seeking but also facilitate the role of the financial system in promoting growth (Levine, 1998).

Against a background of rather disappointing TFP performance, attention to supply-side reform that will lead further from the developmental state model is required generally in East Asia if opportunities for further rapid catch-up are to be fully realized through the efficient management of firms and enhancement of domestic innovation. Thus, developing a legal infrastructure that fosters investor protection and the availability of equity finance appears to be important for research-and-development-intensive activities (Carlin and Mayer, 1998). In the absence of effective control by shareholders, competition is the best discipline on managers' failure vigorously to pursue productivity growth (Nickell, 1996). This 
suggests that the Gerschenkronian neglect of competition policy in East Asia so far is an important error that needs to be rectified.

Comparisons with post-golden age Japan and Western Europe, where most countries have fallen well short of the TFP growth projected for the leading tigers in Table 12 may be instructive in considering whether the tigers will achieve these TFP benchmarks. Thus, slowdown in TFP growth has undermined the 1970s projections for Japan made on a growth accounting basis by Denison and Chung (1976). While they recognized that earlier Japanese growth had a very high transitory catch-up component, they thought that this would not be completely exhausted until about 2002. They projected an average growth rate of 6.2 percent for real GDP from 1971-2000 (Denison and Chung, 1976, p. 126), with growth in the first half of the 1990s still up around 5.5 percent a year.

Why were Denison and Chung wrong? The main reason is that they assumed much stronger growth in TFP from continued catch-up. In fact, Japan has become a somewhat sclerotic economy, in significant part due to excessive regulation, and has weak productivity performance in the nontradables sector. Whereas labor productivity in tradables grew at 4.6 percent a year between 1981 and 1992, in nontradables growth was only 1.9 percent and in services only 0.5 percent a year (Ito, 1996, p. 237). Even in manufacturing, Japan did not close the labor productivity gap with the United States at all between the mid-1980s and the mid-1990s (Pilat, 1996). Significant reforms to the postwar Japanese economic system may well be required before Japan can resume its catch-up of the United States.

The slowdown in European productivity growth after the golden age probably also reflects a reluctance to deregulate even though the postwar settlement no longer delivers fast growth. A quantitative study by Koedijk and Kremers (1996) found that, if West Germany had deregulated its product markets to the same extent as Ireland, its TFP growth in the business sector could have been over 1 percent a year higher. In the European case, a further influence on overall productivity growth has been the rapid growth of the public sector and taxation as a proportion of GDP. While current government spending in the median West European country was 31.9 percent of GDP in 1960-73, in the first half of the 1990 s this had risen to 50.6 percent (OECD, 1995; OECD, 1997). The impact that rising tax burdens have on growth rates is a very controversial topic in applied economics but the trend in recent studies has been to find that an increase of this magnitude in the tax burden could have an appreciable, negative impact on growth of at least 1 and perhaps 2 percent a year (de la Fuente, 1997; Engen and Skinner, 1996; Leibfritz, Thornton, and Bibbee, 1997). Thus, the slowdown in European growth appears to have been exacerbated by policies targeting other objectives.

There are two contrasting implications of this discussion for East Asian growth prospects. First, some aspects of the Asian situation appear more favorable than in the European case, notably, the absence of the pressures of aging on fiscal policy and the lack of a tradition of expensive social programs, which may reduce the risk of rising taxation inhibiting growth. Second, catch-up is not automatic and would tend to be held back by inappropriate policy or inefficient use of capital. The industrial policy prescriptions of the developmental state, which are liable to result in the support of declining industries at the expense of the rapid exploitation 
of new service sector opportunities, are likely to be still less helpful to the next phase of catch-up. Well-handled financial liberalization can help strengthen market disciplines, which will facilitate better productivity performance.

For most of the economies in Table 12, the steady-state growth projection is below the rates achieved in the recent past. There are three reasons for this:

- scope for further catch-up is now reduced, although not exhausted;

- labor force growth will slow appreciably; and

- most countries have been enjoying transitional growth with capital deepening at above the steady-state rate.

The steady-state projections are, however, notable for the relatively modest demands they would place on domestic savings relative to recent levels and could be achieved with lower domestic investment rates than have prevailed in the past. Given that demographic factors will not tend to reduce domestic savings much even in the countries where the demographic transition is most advanced before 2010 (Heller and Symansky, 1997), savings would not seem to be a constraint on achieving these growth rates. One way for growth to be higher than these projections would be for countries to continue to invest more. For example, if Korea and Singapore, while sustaining the TFP growth of Table 12, invested sufficiently to reach the Japanese capital to output ratio of 4.6 by 2015, growth of real GDP per person would be projected over the 20-year period to average 5.1 and 3.7 percent, respectively.

This review of Asian growth prospects essentially represents the situation before the present crisis. Indeed, the TFP growth rates chosen to illustrate the steady-state paths are broadly within the range thought likely in a recent precrisis OECD projection that projected TFP growth for "dynamic Asia" at 2.0 to 2.8 percent and for China at 2.0 to 3.4 percent a year through 2020 (Richardson, 1997). It is surely too soon to be sure how much has changed or even how many countries will eventually become directly rather than indirectly affected by financial and/or currency crises.

Some favorable features of strong growth countries will presumably be resilient - these might include stocks of human capital, high personal savings, and effective mechanisms for technology transfer and their outward orientation. Others, such as high investment rates, are likely to be undermined in the short term, although not necessarily in the longer term, as U.S. experience during the Great Depression suggests. In that case, the economy returned to its earlier trend growth path by the early 1940s (Ben-David and Papell, 1995). The 1930s U.S. example argues that even a massive financial crisis need not damage long-term growth potential provided that the banking system is rehabilitated and reregulated (Crafts, 1999).

The most intriguing aspect of the crisis is whether it will tend to promote favorable institutional and policy innovations, leading to improved productivity performance and better use of capital. There is no model available that we can turn to for predictions, though it is sometimes claimed that crisis may be necessary to overcome the status quo bias of politics as usual and thus to facilitate reform packages. Rodrik (1996, pp. 28-9) has argued that in deep crisis it is possible to deliver widespread income gains by policies to revive economic activity and that this may 
allow reformist policymakers to add on microeconomic and structural reforms that would be difficult to implement in normal times because of their distributional implications. Given that microeconomic reform to the Asian developmental state model is clearly required, it is possible that the crisis could actually be helpful to long-term growth despite its devastating short-term impact.

\section{Conclusions}

It is now time to reflect on the questions posed in the introduction in the light of the discussion of the intervening sections of the paper. The comments to be made are in the nature of generalizations that really deserve to be heavily nuanced and qualified but may nevertheless serve a useful purpose by provoking others to react.

Three special aspects of East Asian growth have been highlighted. First, compared with the European golden age, it is the factor accumulation of the region rather than its TFP growth that has been most impressive. High investment has been a striking achievement of the policies adopted by countries in the region with regard to both physical and human capital. Having said this, productivity performance has been stronger than expected by the most strident critics. Second, the population profile of East Asian growth marks it out as different, especially in the tigers that have experienced a temporary demographic gift of rising labor force participation in recent decades. Third, in many countries development has occurred rapidly from an initial position of "economic backwardness" and this has generated its own legacy of financial and other institutions. This history does exert an influence, both positive and negative, on future growth prospects.

The current Asian crisis seems to owe a great deal to the weakness of financial systems, reflected in overborrowing and excessive investment together with inadequate regulatory responses. This probably says more about the way that financial liberalization has been handled than about the fundamental growth potential of the economies concerned. Nevertheless, the Korean experience, in particular, does suggest that its earlier approach to financial market decision making and regulation left the economy badly exposed to a high risk that financial liberalization would turn out badly and thus jeopardized long-run growth.

This tends to suggest that there are downsides to the "developmental state" model that its proponents tend to gloss over-in particular its tendency to wasteful investment and the difficulties that it may pose for an eventual transition to a freer capital markets model. The latter will tend to grow in attractiveness after the initial phase of development when coordination problems loom much less large and diminishing returns become a bigger threat, such that efficient use rather than sheer volume of investment becomes a higher priority. The greatest successes of the managed development approach have tended to come in the context of exportorientated manufacturing and industrialization. In the coming years of deindustrialization, a different model may be more appealing. 


\section{REFERENCES}

Abramovitz, Moses, 1986, "Catching-Up, Forging Ahead, and Falling Behind," Journal of Economic History, Vol. 36 (June), pp. 385-406.

Amsden, Alice H., 1989, Asia's Next Giant (New York: Oxford University Press).

Asian Development Bank, 1997, Asian Development Outlook 1997 and 1998 (Manila, Philippines: ADB).

Barro, Robert J., 1997, Determinants of Economic Growth: A Cross-Country Empirical Study (Cambridge, Massachusetts: MIT Press).

Bean, Charles, and Nicholas Crafts, 1996, "British Economic Growth Since 1945: Relative Economic Decline ... and Renaissance?" in Economic Growth in Europe Since 1945, ed. by Nicholas Crafts and Gianni Toniolo (Cambridge: Cambridge University Press), pp. 131-72.

Beason, Richard, and David E. Weinstein, D. E. (1996), "Growth, Economies of Scale and Targeting in Japan (1955-1990)," Review of Economics and Statistics, Vol. 78 (May), pp. 286-95.

Benhabib, Jess, and Mark M. Spiegel, 1994, "The Role of Human Capital in Economic Development: Evidence from Cross-Country Data," Journal of Monetary Economics, Vol. 34 (October), pp. 143-73.

Ben-David, Dan, and David H. Papell, 1995, "The Great Wars, the Great Crash and Steady State Growth: Some New Evidence about an Old Stylized Fact," Journal of Monetary Economics, Vol. 36 (December), pp. 453-75.

Bernard, Andrew B., and Steven N. Durlauf, 1995, "Convergence in International Output," Journal of Applied Econometrics, Vol. 10 (April-June), pp. 97-108.

Bloom, David E., and Jeffrey G. Williamson, 1997, "Demographic Transitions and Economic Miracles in Emerging Asia," World Bank Economic Review, Vol. 12 (September), pp. 419-55.

Borensztein, Eduardo, and Jong-Wha Lee, 1999, "Credit Allocation and Financial Crisis in Korea," IMF Working Paper 99/20 (Washington: International Monetary Fund).

Caprio, Gerard, 1998, "Banking on Crises: Expensive Lessons from Recent Financial Crises," World Bank Policy Research Working Paper No. 1979 (Washington: World Bank).

Carlin, Wendy, and Colin Mayer, 1998, "Finance, Investment and Growth,” Discussion Papers on Economics No. 98-09 (London: University College, Department of Economics).

Collins, Susan M., and Barry P. Bosworth, 1996, "Economic Growth in East Asia: Accumulation Versus Assimilation," Brookings Papers on Economic Activity: 2, Brookings Institution, pp. 135-91.

Crafts, N.F.R., 1997, "Economic Growth in East Asia and Western Europe Since 1950: Implications for Living Standards," National Institute Economic Review, Vol. 162 (October), pp. 75-84.

_ 1999, "Implications of Financial Crisis for East Asian Trend Growth," Oxford Review of Economic Policy, Vol. 15, forthcoming.

— , and Gianni Toniolo, 1996, "Postwar Growth: An Overview," in Economic Growth in Europe Since 1945 (Cambridge: Cambridge University Press), pp. 1-37.

Dahlman, Carl J., 1994, “Technology Strategy in East Asian Developing Economies," Journal of Asian Economics, Vol. 5 (Winter), pp. 541-72.

Denison, Edward F., and William Chung, eds., 1976, How Japan's Economy Grew So Fast: The Source of Postwar Expansion (Washington: Brookings Institution).

Easterly, William, and Stanley Fischer, 1995, "The Soviet Economic Decline," World Bank Economic Review, Vol. 9 (September), pp. 341-71. 


\section{Nicholas Crafts}

EBRD, 1997, Transition Report (London: EBRD).

Eichengreen, Barry, 1996, "Institutions and Economic Growth; Europe after World War II," in Economic Growth in Europe Since 1945, ed. by Nicholas Crafts and Gianni Toniolo (Cambridge: Cambridge University Press), pp. 38-72.

Engen, Eric M., and Jonathan Skinner, 1996, “Taxation and Economic Growth,” National Tax Journal, Vol. 49 (December), pp. 617-42.

de la Fuente, Angel, 1997, "Fiscal Policy and Growth in the OECD," CEPR Discussion Paper No. 1755 (London: Centre for Economic Policy Research).

Fukuda, Shin-ichi, 1999, "Sources of Economic Growth in East Asian Economies: Why Did Capital Stock Grow So Rapidly?," Structural Aspects of the East Asian Crisis, by the Organization for Economic Coordination and Development (Paris: OECD), pp. 29-56.

Gerschenkron, Alexander, 1962, Economic Backwardness in Historical Perspective: A Book of Essays (Cambridge, Massachusetts: Belknap Press).

Hanna, Nagy, Sander Boyson, and Shakuntala Gunaratne, 1996, The East Asian Miracle and Information Technology: Strategic Management of Technological Learning (Washington: World Bank).

Heller, Peter S., and Steve Symansky, 1997, "Implications for Savings of Aging in the Asian 'Tigers,"' IMF Working Paper 97/136 (Washington: International Monetary Fund).

Hsieh, Chan-Tau, 1997, "What Explains the Industrial Revolution in East Asia? Evidence from Factor Markets," Discussion Papers in Economic No. 196 (Cambridge, Massachusetts: Woodrow Wilson School of International Affairs, Princeton University).

$\mathrm{Hu}$, Zuliu F., and Mohsin S. Khan, 1997, "Why Is China Growing So Fast?," Staff Papers, International Monetary Fund, Vol. 44 (March), pp. 103-31.

Islam, Nazrul, 1995, "Growth Empirics: A Panel Data Approach," Quarterly Journal of Economics, Vol. 110 (November), pp. 1127-70.

Ito, Taketoshi, 1996, “Japan and the Asian Economies: A 'Miracle' in Transition," Brookings Papers on Economic Activity: 2, Brookings Institution, pp. 205-72.

Knack, Stephen, and Philip Keefer, 1995, "Institutions and Economic Performance: CrossCountry Tests Using Alternative Institutional Measures," Economics and Politics, Vol. 7, (November), pp. 207-27.

Koedijk, Kees, and Jeroen Kremers, 1996, "Market Opening, Regulation and Growth in Europe," Economic Policy, Vol. 23 (October), pp. 445-67.

Krugman, Paul, 1994, “The Myth of Asia's Miracle," Foreign Affairs, Vol. 73 (November-December), pp. 62-78.

Lee, Jong-Wha, 1995, "Government Interventions and Productivity Growth in Korean Manufacturing Industries," NBER Working Paper No. 5060 (Cambridge, Massachusetts, National Bureau of Economic Research).

Leibfritz, Willi, John Thornton, and Alexandra Bibbee, 1997, "Taxation and Economic Performance," OECD Economics Department Working Paper No. 176 (Paris: OECD).

Levine, Ross, 1996, "Financial Development and Economic Growth: Views and Agenda," World Bank Policy Research Working Paper No. 1678 (Washington: World Bank).

— 1998, "The Legal Environment, Banks, and Long-Run Economic Growth,” Journal of Money, Credit and Banking, Vol. 30 (August), pp. 596-611.

Maddison, Angus, 1991, Dynamic Forces in Capitalist Development: A Long-Run Competitive View (Oxford: Oxford University Press).

—, 1995, Monitoring the World Economy, 1820-1992 (Paris: OECD). 
, 1996, "Macroeconomic Accounts for European Countries," in Quantitative Aspects of Postwar European Economic Growth, ed. by Bart van Ark and Nicholas Crafts (Cambridge: Cambridge University Press), pp. 27-83.

__ 1997, The Nature and Functioning of European Capitalism: A Historical and Comparative Perspective (Groningen: Growth and Development Centre).

—, 1998, Chinese Economic Performance in the Long Run (Paris: OECD).

Mankiw, N. Gregory, 1995, "The Growth of Nations," Brookings Papers on Economic Activity 1, Brookings Institution, pp. 275-310.

— David Romer, and David N. Weil, D. 1992, "A Contribution to the Empirics of Economic Growth,” Quarterly Journal of Economics, Vol. 107 (May), pp. 407-38.

McKinnon, Ronald I., and Huw Pill, 1996, "Credible Liberalizations and International Capital Flows: The 'Overborrowing Syndrome,'” Financial Deregulation and Integration in Asia, ed. by Takatoshi Ito and Anne O. Krueger (Chicago: University of Chicago Press), pp. 7-42.

Milbourne, R., 1995, "Factor Convergence versus Productivity Convergence," paper presented to the 7th World Econometrics Congress, Tokyo.

Mills, Terence C., and Nicholas Crafts, 1999, "After the Golden Age: A Long Run Perspective on Growth Rates that Speeded Up, Slowed Down and Still Differ," The Manchester School, forthcoming.

Mishkin, Frederic. 1997, "Understanding Financial Crises: A Developing Country Perspective,” NBER Working Paper No. 5600 (Cambridge, Massachusetts: National Bureau of Economic Research).

Nelson, Richard R., and Gavin Wright, 1992, “The Rise and Fall of American Technological Leadership: The Postwar Era in Historical Perspective," Journal of Economic Literature, Vol. 30 (December), pp. 1931-64.

Nickell, S.J. 1996, “Competition and Corporate Performance," Journal of Political Economy, Vol. 104 (August), pp. 724-46.

Noguchi, Yukio, 1998, “The 1940 System: Japan Under the Wartime Economy," American Economic Review, Papers and Proceedings, Vol. 88 (May), pp. 404-407.

OECD, 1995, Historical Statistics, 1960-1993 (Paris: OECD).

1997, Economic Outlook (Paris: OECD).

, 1998, Employment Outlook (Paris: OECD).

Olson, Mancur, 1982, The Rise and Decline of Nations: Economic Growth, Stagflation, and Social Rigidities (New Haven, Connecticut: Yale University Press).

Oulton, Nicholas, and Garry Young, 1996, "How High is the Social Rate of Return to Investment?" Oxford Review of Economic Policy, Vol. 122 (Summer), pp. 48-69.

Park, Yung-Chul, 1994, "Concepts and Issues," in The Financial Development of Japan, Korea, and Taiwan: Growth, Repression and Liberalization, ed. by Hugh T. Patrick and Yung-Chul Park (New York: Oxford University Press), pp. 3-26.

Pilat, Dirk, 1996, "Labour Productivity Levels in OECD Countries: Estimates for Manufacturing and Selected Service Sectors," OECD Economics Department Working Paper No. 169 (Paris: OECD).

Republic of Indonesia, 1997, Labor Force Survey (SAKERNAS) (Jakarta: Biro Pusat Statistik).

Republic of the Philippines, 1973, BCS Survey of Households Bulletin: Labor Force (Manila: Bureau of Census and Statistics).

—, 1993 , Integrated Survey of Households Bulletin: Labor Force (Manila: Bureau of Census and Statistics). 
Republic of Thailand, 1973, Report of the Labor Force Survey (Bangkok: National Statistical Office).

___ 1996, Report of the Labor Force Survey: Whole Kingdom (Bangkok: National Statistical Office).

Richardson, Pete, ed., 1997, "Globalization and Linkages: Macrostructural Challenges and Opportunities," OECD Economics Department Working Paper No. 181 (Paris: OECD).

Rodrik, Dani, 1995, "Getting Interventions Right: How South Korea and Taiwan Grew Rich," Economic Policy, Vol. 20 (April), pp. 55-107.

— 1996, "Understanding Economic Policy Reform," Journal of Economic Literature, Vol. 34 (March), pp. 9-41.

— 1997, "TFPG Controversies, Institutions and Economic Performance in East Asia," CEPR Discussion Paper No. 1587 (London: Centre for Economic Policy Research).

Rossi, Nicola, Andrea Sorgato, and Gianni Toniolo, 1992, "Italian Historical Statistics, 1890-1990," University of Venice Dipartimento di Scienze Economiche Working Paper No. 92-18 (Venice: University of Venice).

Rossi, Nicola, and Gianni Toniolo, 1996, "Italy," in Economic Growth in Europe Since 1945, ed. by Nicholas Crafts and Gianni Toniolo (Cambridge: Cambridge University Press), pp. 427-54.

Sala-i-Martin, Xavier, 1994, "Regional Cohesion: Evidence and Theories of Regional Growth and Convergence," CEPR Discussion Paper No. 1075 (London: Centre for Economic Policy Research); also published in European Economic Review, Vol. 40 (June 1996), pp. 1325-52.

Sarel, Michael, 1997, "Growth and Productivity in ASEAN Countries," IMF Working Paper 97/97 (Washington: IMF).

Smith, Heather, 1995, "Industry Policy in East Asia," Asian-Pacific Economic Literature, Vol. 9 (May), pp. 17-39.

Timmer, M.P. and A. Szirmai, 1997, "Growth and Divergence in Manufacturing Performance in South and East Asia," Research Memorandum GD-37, University of Groningen Growth and Development Centre (Groningen, Germany: University of Groningen).

United Nations, 1995, World Population Prospects (New York: UN).

Van Ark, Bart, and Nicholas Crafts, 1996, "Catch-Up, Convergence and the Sources of Postwar European Economic Growth: Introduction and Overview," in Quantitative Aspects of Postwar European Economic Growth, ed. by Bart van Ark and Nicholas Crafts (Cambridge: Cambridge University Press), pp. 1-26.

Wade, Robert, 1990, Governing the Market (Princeton: Princeton University Press).

Wei, Shang-Jin, 1997, "How Taxing is Corruption on International Investors?,” NBER Working Paper No. 6030 (Cambridge, Massachusetts: National Bureau of Economic Research).

Weingast, Barry R. 1995, "The Economic Role of Political Institutions: Market-Preserving Fiscal Federalism and Economic Development," Journal of Law, Economics, and Organization, Vol. 11 (April), pp. 1-31.

Young, Alwyn, 1994, "Accumulation, Exports and Growth in the High Performing Asian Economies: A Comment," Carnegie-Rochester Conference Series on Public Policy, Vol. 40 (June), pp. 237-50.

— 1995, "The Tyranny of Numbers: Confronting the Statistical Realities of the East Asian Growth Experience," Quarterly Journal of Economics, Vol. 110 (August), pp. 641-80.

1998, "Alternative Estimates of Productivity Growth in the NICs: A Comment on the Findings of Chang-Tai Hsieh," NBER Working Paper No. 6657 (Cambridge, Massachusetts: National Bureau of Economic Research). 